\title{
Perspective
}

PERSPECTIVE Actualité en histoire de l'art

2| 2015

United States

\section{From the culture wars to a civil war: institutes of art-historical research in the United States}

\section{Elizabeth Mansfield}

\section{Q OpenEdition \\ 1 Journals}

\section{Electronic version}

URL: http://journals.openedition.org/perspective/5958

DOI: 10.4000/perspective.5958

ISSN: 2269-7721

\section{Publisher}

Institut national d'histoire de l'art

\section{Electronic reference}

Elizabeth Mansfield, «From the culture wars to a civil war: institutes of art-historical research in the United States », Perspective [Online], 2 | 2015, Online since 07 December 2015, connection on 01 October 2020. URL : http://journals.openedition.org/perspective/5958 ; DOI : https://doi.org/10.4000/ perspective.5958

This text was automatically generated on 1 October 2020 . 


\title{
From the culture wars to a civil war: institutes of art-historical research in the United States
}

\author{
Elizabeth Mansfield
}

1 The history of institutes for advanced research in the visual arts in the United States is a recent one, dependent as much on the happy accidents of Fortune as of fortune. Great fortunes made in banking and the oil business, especially, but also fortunes generated by a successful chain of discount stores and a sewing machine empire provided the funds needed to found all of the major art history research centers in the United States: the Getty Research Institute, the Center for Advanced Study in the Visual Arts (CASVA), the Yale Center for British Art, and the Clark Art Institute. While the establishment of these institutions within two decades of each other may suggest a deliberate public program for the enhancement of American scholarship on the history of art, this was not the case: each appeared independently, a product of the personal ambitions, aesthetic affinities and philanthropic impulses of its founder. Yet, regardless of the disparate origins of these institutions, theirs is also a collective history. The larger forces that shaped late twentieth-century American society also contributed to the missions and status of these institutions. In turn, these institutions would play a decisive role in shaping art history's course into the twenty-first century.

2 Americans' attitudes toward public sponsorship of humanities research underwent a marked reorientation in the last decades of the twentieth century, retreating from the idea that intellectual and cultural attainments might be matters of national interest. Earlier in the century, there was a newfound interest in government subsidies for creating, preserving, and interpreting cultural heritage. This sympathy revealed itself with New Deal legislation enacted in the 1930s that allowed for intellectual and artistic labor to be understood as worthy of public support. The introduction of the GI Bill during the Second World War then codified the belief that higher education-in the arts and humanities as well as the sciences -amounted to a public good. ${ }^{1}$ Finally, the Great Society reforms enacted during the presidency of Lyndon B. Johnson in the mid-1960s 
further instantiated the idea that the creation and study of art was a proper area for government intervention: passage of the National Foundation of the Arts and the Humanities Act of 1965 established government agencies charged with supporting the work of artists and scholars through grants to individuals and institutions. The Act states that "a high civilization must not limit its efforts to science and technology alone but must give full value and support to the other great branches of man's scholarly and cultural activity" ${ }^{2}$. Throughout the Act, humanities scholarship and arts production are cast as essential for a functioning democracy. Acknowledging that private individuals and local agencies must always be the primary sponsors of arts and letters, the Act nevertheless claims that "it is necessary and appropriate for the Federal Government to complement, assist, and add to programs for the advancement of the humanities and the arts."

By the mid-1970s, however, popular support for government expenditures on behalf of arts and letters was eroding. It was at precisely this moment of public equivocation about the relationship between humanities scholarship and democratic society that America's major research institutes devoted to art history came into being. To understand these places is to reckon, first, with the influence of the so-called "culture wars" on American intellectual and academic life and, second, with the concomitant bifurcation of American art history into historical and contemporary branches.

Skepticism toward the government's direct sponsorship of the production and study of culture was expressed in the 1970s by politicians and policy makers who identified themselves as conservatives. The designation "conservative" was used by a range of Americans at this time to signal a variety of sympathies. For some, it represented a rejection of the radicalism summarized by 1968 and a belief that the government's adoption of such progressive mandates as affirmative action, rent subsidies for the poor, and urban beautification were not just beyond the purview of federal authority but were also threatening to destabilize the country's political system and economy. These fiscal conservatives proclaimed adherence to free-market principles in virtually all areas of society. But they were not the only ones to embrace the label "conservative." Others identified themselves as conservatives in order to assert their commitment to a set of cultural values, loosely understood as "traditional" and "Christian." These self-described conservatives focused mostly on establishing-by legal or other social means - limits on personal behaviors that threatened to deviate from patriarchal and heterosexist norms. For this group, then, conservatism involved shaping personal values and behavior through various forms of cultural policing. For conservatives of either cast, government support for humanities research including scholarship in art history was anathema. Fiscal conservatives believed such work should be funded privately; cultural conservatives disliked the pluralism that seemed an unavoidable part of government sponsorship.

5 Shortly after Ronald Reagan's election as president in November of 1980, two committees were established to develop the incoming administration's policies on cultural and intellectual affairs. Hanging in the balance during these deliberations were the fates of the two funding agencies created by the National Foundation of the Arts and the Humanities Act: the National Endowment for the Arts (NEA) and the National Endowment for the Humanities (NEH). A portion of NEA and NEH budgets was designated for distribution to individual scholars, who would compete for grants. American academics, including professors of art history, would typically apply for 
funds to support research undertaken during their sabbatical leaves. Academics' salaries are normally reduced by half during a scheduled research leave, and granting agencies like the NEA and NEH provided necessary salary relief. Visual arts scholars might apply for funding from either the NEA or NEH, depending on the kind of work they were doing. Art historians engaged in curatorial activities or in art or architectural preservation might petition the NEA for support; scholars pursuing historical research or interpretive analysis would instead seek funding from the NEH. The recommendations of these advisory committees were not published, but conservative art critic Hilton Kramer was sufficiently briefed on their deliberations to report on them for The New York Times (KRAMER, 1980). Among the committee members named by Kramer were Richard J. Bishirjian and Robert S. Carter; William J. Bennett is identified as a "consultant." Exemplary of their positions on culture and scholarship are, among others, the volume edited by Bishirjian, A Public Philosophy Reader (1978), Bennett's, The De-valuing of America: The Fight for Our Culture and Our Children (1992), and his Our Children and Our Country: Improving America's Schools and Affirming the Common Culture (1988).

6 According to Kramer, both committees homed in on a single, overriding problem: the Endowments' shift away from support for "pure" creative or scholarly work and toward "social service" and "political, or politicized" programs. While everyone involved in the discussions believed that there were problems with the NEA and NEH, they did not agree on a solution. Kramer discerned a struggle between two factions across both committees. One faction maintained that sponsorship of arts production and humanities scholarship was within the federal government's purview. For this group, it was simply a matter of directing the efforts of these agencies toward supporting "serious art" and "scholarly excellence". To illustrate what conservatives did not believe to be exemplary of "scholarly excellence," Kramer cited the NEH-funded "Working Women" project, which involved the creation of educational materials and cultural events devoted to the history of office workers. While no specific examples of "scholarly excellence" were mentioned in Kramer's article, it is possible to surmise what was meant by this term by reviewing published statements by the committee members and consultants he names: disinterested research devoted to canonical works of Western literature, philosophy, and the arts. The second faction called for nothing short of the immediate dismantling of both the NEH and the NEA. Kramer admitted that he could not foresee which faction would prevail, and he rightly predicted that any changes to federal policies on funding for the arts and humanities would not be implemented immediately. Ultimately, both factions were able to claim victory. Programming at the two agencies was redirected away from social engagement or advocacy beginning in the 1980s, and sharp budget cuts followed in the 1990s.

7 Of course, not all Americans found fault with the cultural and scholarly ambitions of the Great Society reforms of the 1960s. However, the intellectual and artistic life of the nation had become sufficiently politicized in the late 1970s and 1980s that many in the United States accepted the presumptive stakes of what conservatives labeled the "culture wars." This campaign to demonize intellectual, academic, or artistic efforts that were seen to validate progressivism was cast by conservatives as a fight against lax standards, multiculturalism, anti-Americanism, and, worst of all, "relativism." For progressives, the culture wars were viewed as a rear-guard action intended to limit academic freedom and restore traditional race-, gender-, and class-specific barriers to education and other forms of cultural capital. Perhaps more than any other site of 
battle, the canon of Western culture provided an imagined high ground on which conservatives encamped their army. University faculties were quickly embroiled. Public institutions, in particular, came under increasing surveillance by conservative activists. Efforts by humanities professors to expand their teaching and research agendas to include new forms of cultural expression were politicized by the right and used to rally popular support for the defunding of programs viewed as inconsistent with conservative aims. ${ }^{3}$

8 This painfully simplified account of American conservatism and its prosecution of the culture wars is a necessary backdrop for any account of the Getty Research Institute, CASVA, the Yale Center for British Art, and the Clark's Research and Academic Programs office. The appearance of these institutions during America's reorientation away from Great Society reforms and toward its current neoliberalism is a historical coincidence as redolent of triumph as it is of irony. On the one hand, art historians found themselves the greatest beneficiaries of these institutions' timely largesse. As funding from sources like the NEH has decreased significantly over the course of the past three decades and as many universities struggle to maintain support for humanities research, the Getty, CASVA, the Yale Center for British Art, and the Clark have given out millions of dollars to individual scholars.

9 Financial support is only part of these institutes' boon to art history. Each year, their residential fellowship programs create intellectual communities that give rise to sustained scholarly interaction and collaboration, creating research networks that span the globe. What is more, these research institutes are also publishers, providing art historians with additional venues for their work even as many university presses are contracting or closing altogether. On the other hand, these institutions were not especially inclined at first to provide relief from conservative efforts to reaffirm the primacy of the traditional Western canon. As privately-financed organizations with explicit or implicit mandates to promote advanced research on canonical Western art history, these institutions have contributed to a scholarly economy in the United States that has, until recently, turned on monographic and collections-based studies in areas deemed culturally important by America's Gilded Age collectors and philanthropists. Furthermore, the exclusion of contemporary art from the original research programs of the Getty, CASVA and the Yale Center for British Art helped to create a disciplinary rift that would have major repercussions for art history in the early twenty-first century.

\section{Getty Research Institute}

10 There is no more significant date in the history of the Getty Research Institute than June 6, 1976, the day that J. Paul Getty died. His generosity toward the California museum that bore his name surprised its curators as much as anyone. In the years leading up to his death, Getty had warned the museum staff not to expect too much when he died (DAVIS, 2007, p. 286-87). When it became clear that the bequest amounted to three-quarters of a billion dollars, the museum's trustees realized that the institution - as it was then conceived - could not manage the income generated by an endowment of that size. With new trustees recruited to help reimagine the mission of the J. Paul Getty Museum, the Getty Center for the History of Art and Humanities was conceived as a complement to the museum and to a proposed conservation facility and 
program. Plans to create the Getty Center were announced in 1982. A residential scholars program, a major research library, a comprehensive digital archive of the world's art, and a reference division charged with developing new tools for arthistorical research were included in the scheme. As the new research programs were organized and launched - the first Getty Scholars were in residence during the 1985-1986 academic year - the Trust continued to grow. When the Getty board decided to convert the Trust's assets from shares in Getty Oil stock to cash by selling the company to Texaco the endowment topped $\$ 1$ billion, thus emboldening the board to consider expanding the size of the Getty in accordance with its new programmatic ambitions. A new building, designed by Richard Meier and completed at a cost of roughly \$1.3 billion, opened in 1997 in Los Angeles. The Center for the History of Art and the Humanities - rechristened in 1996 as the Getty Research Institute for the History of Art and the Humanities -moved to the new building. Since 1999, the program has been known simply as the Getty Research Institute (GRI).

11 The trustees who created the original Getty Center for the History of Art and the Humanities in 1982 also limited the thematic and chronological scope of the Getty Museum to European art before 1900 (DAVIS, 2007, p. 301). The rationale for this mandate was, in part, the belief that the Getty should stick to its last. Asian art, modern European art, British art, and contemporary art were seen as already well represented by other area institutions, principally the Los Angeles County Museum of Art, the Norton Simon Museum, the Pacific Asia Museum, the Huntington Library, and the new Los Angeles Museum of Contemporary Art. Only by circumscribing its mission around the best parts of its original collections could the Getty gain the depth of holdings it would need to really distinguish itself. But there was another motivation for limiting the museum's purview in this way. Some of the trustees recognized that the Getty Museum would have the resources to acquire virtually any work that came on the market. To compete directly with neighboring museums and cultural institutions would be a disservice to the community and, ultimately, to the Getty itself.

The impact of the museum's focus on European art before 1900 on the scope of the research programs undertaken by the Getty Center for the History of Art and the Humanities was mitigated by the ambitious interdisciplinary character of the Getty Scholars Program. This fellowship program brings together up to a dozen senior scholars for academic-year residencies in the company of a smaller group of predoctoral and postdoctoral fellows and numerous short-term visiting scholars. Each year is devoted to a particular theme. Some participants are invited to join the cohort while others are selected on the basis of an application that undergoes external and internal review. Not limited to the field of art history, Getty Scholars come from a variety of fields and the mix is intended to promote interdisciplinary discussion and collaboration. Scholars from countries other than the United States have always been well represented in the program. Even so, the Getty Center for the History of Art and the Humanities offered a timely counterpoint to the advancing public disavowal of support for humanities research in America. The Center began offering fellowships to scholars - whether based in America or not - just as the culture wars were beginning to influence funding decisions at the NEH and research agendas at public universities. This timing meant that at least some art history scholars would be able to pursue their work unimpeded. 
13 A review of the rosters of Getty Scholars from the first dozen years of the program suggests a striking methodological heterogeneity. ${ }^{4}$ In this way, too, then, the Getty provided a respite from the culture wars for some American art historians. What remained mostly outside of the Getty's purview until the past decade or so, however, was robust support for research on contemporary art. Projects expressly devoted to the study of contemporary art become more evident after 1999, when the GRI came under the direction of Thomas Crow, whose own research interests include post-war American art. The Getty Museum and Foundation likewise began to enhance their engagement with contemporary art in late 1990s. Initiatives such as the 2000-2002 Art Matters lecture series and the ongoing Pacific Standard Time exhibitions ${ }^{5}$ and related scholarly programs are notable examples of this new enthusiasm. Even so, the GRI's initial neglect of this area had symbolic as well as material consequences for the field. It was, as the following paragraphs will suggest, one of many moments of institutional pressure on the discursive formation of contemporary art studies.

While the impact of the Getty Center on the disciplinary economy of art history is still revealing itself, its effect on America's cultural geography was immediate: the creation in California of an institution devoted to acquiring, preserving, and interpreting the visual arts with a billion dollar endowment (now over $\$ 6$ billion) reoriented the cultural geography of the United States. The Northeast had always been the presumptive locus of advanced art-historical research in the United States. Since the discipline was introduced to American academe in the late nineteenth century, art history's institutional culture was dominated by universities and museums located in Boston, New York, Philadelphia, and Washington, DC. Even the early twentieth-century establishment in California of such important arts institutions as the Norton Simon Museum and the Huntington Library and the rise of academic institutions like CalArts and University of California, Berkeley could not shake long-standing popular as well as scholarly attachment to the idea that the northeast remained the center of advanced visual arts production and art-historical scholarship. It would take the Getty's unparalleled resources and ambitious mission to refocus art historians' perceptions of the country's cultural and institutional geography.

\section{Center for Advanced Study of the Visual Arts}

Since its creation in 1949, the National Gallery of Art in Washington, DC has occupied the symbolic center of American research into the visual arts. Established through private donations, the National Gallery of Art relies on its endowment for acquisitions and some of its scholarly programming, while staff members' salaries, and building maintenance and management are paid with public funds. ${ }^{6}$ Most Americans are unaware of the hybrid organization of the National Gallery of Art, and its presence on the National Mall of the capital suggests that the museum is a wholly public institution. For this reason, the research programs of the National Gallery of Art enjoy a quasiofficial status as the flagship institute for scholarship on the visual arts.

Though the scope of scholarly programming increased dramatically in the late 1970s, advanced art- historical research has always been part of the National Gallery of Art's mission. An annual lecture series commenced at the time of the institution's founding and was named for its main benefactor, Andrew W. Mellon (1855-1937). These lectures were to be delivered by an eminent scholar and in some way addressed to the artworks 
in the museum. Seeded by the personal collections of Andrew Mellon and Samuel H. Kress (1863-1955), the National Gallery of Art was primarily a repository for European painting, sculpture and works on paper. The trustees of the Samuel H. Kress Foundation acknowledged the importance of ongoing collections-based scholarship for the legacy of its namesake, and endowed the Kress Professorship in 1965. This post would revolve annually and would be awarded to a scholar undertaking research related to European art in the National Gallery.

Andrew Mellon's children, Paul Mellon and Ailsa Mellon Bruce, transformed the research program at the National Gallery decisively in 1971 by pledging the funds necessary to enlarge the museum and introduce a much expanded research division. The new East Wing, designed by I. M. Pei, would provide offices, event spaces, and a library to support the new Center for Advanced Study in the Visual Arts (CASVA). When the building was finished in 1979, CASVA became the home of the Kress Professor and the host of the Andrew W. Mellon Lectures. An enhanced fellowship program brought more senior scholars to the National Gallery for residencies, augmenting the existing pre-doctoral fellowships. During CASVA's inaugural fellowship year, 1980-81, four senior fellows pursued academic-year fellowships and eight others came for shorter residencies. All but two came from American institutions. Now, in addition to the Kress Professorship, CASVA offers two other annually rotating professorships along with ten to fifteen senior or visiting senior fellowships, a two-year postdoctoral fellowship, and nine predoctoral fellowships. As the program matured, international scholars would make up a significant proportion of the Senior Fellows and visiting professors. ${ }^{7}$

There is no question that CASVA's pre- and postdoctoral fellowships have played an influential part in the institutional history of art history in America. Fully a generation of American art historians has been defined by the availability of CASVA fellowships at two decisive career moments. Few predoctoral fellowships accord recipients with the resources to undertake research travel and then to write the dissertation that CASVA awards provide. Not surprisingly, past recipients of CASVA predoctoral fellowships number among today's most prominent American scholars. Likewise, CASVA Senior Fellowships provide financial support and prestige in equal measure, allowing established academics to participate in a residential study program with stimulating colleagues. Just as importantly, a CASVA award confers status among American art historians: it is seen as a mark of scholarly arrival.

19 This disciplinary cachet remained somewhat entailed, however, in CASVA's early history. Though not explicitly mandated, CASVA's research program tended toward what might be termed "traditional" art-historical scholarship. By "traditional" here is meant positivist modes of inquiry that rely on research questions and methodologies well established before the 1980s: problems of attribution and chronology, questions of iconographic analysis, histories of patronage, inquiries into patterns of formal influence and propagation of style. That the kind of research supported by CASVA should incline toward positivist methods is understandable and even appropriate given the program's history as a scholarly arm of a museum founded upon the Mellon and Kress collections. Art of the post-war era, too, remained mostly outside CASVA's bailiwick during its first two decades. Not until 1995 would the Mellon Lectures address a postwar topic, and even then the encounter was tempered. By inviting philosopher and art critic Arthur Danto to deliver the lectures, CASVA's program directors subtly signaled that contemporary art remained perhaps too contingent for historical 
consideration, too ephemeral for the positivist methods of traditional art history. Slightly less tentative was the establishment in 2013 of the William C. Seitz Senior Fellowship, which is "primarily intended to support research on modern and contemporary art." 8

\section{Yale Center for British Art}

The capacity for a single donor to influence the direction of advanced research in art history is nowhere better exemplified than by the Yale Center for British Art. A selfdescribed Anglophile, Paul Mellon identified strongly with the birthplace of his English mother and spent long stretches of time in the United Kingdom throughout his life (MELLON, BASKETT, 1992). His attraction to British art was, according to Mellon, both instinctive and calculated: he recognized in the 1950s that he could acquire British artworks of high quality for comparatively little money, whereas good examples by European Old Masters were both expensive and difficult to come by. His focus on British art also allowed him to differentiate his collecting activities from those famously undertaken by his father, Andrew W. Mellon. Paul Mellon further distinguished himself by bequeathing the lion's share of his collection not to the American people as his father had done, but to an institution that would bear his name. In a further departure from his father's approach to collecting, Paul Mellon took into account from the first the need to foster a scholarly adjunct to his program of acquisition and exhibition; he would later insist that scholarship play as important a role as his collection at the Yale Center for British Art.

Paul Mellon resolved to collect British art systematically and energetically in 1959, and then only because he had become acquainted with an art historian he believed could provide both the necessary expertise and the vision to conceive of the unparalleled collection Mellon aimed to assemble in the United States. Basil Taylor left his post at the Royal College of Art in 1961 to devote himself entirely to securing works for Mellon. Taylor's distaste for the financial conflicts of interest inherent to the trade led him to refuse any payment for his services, a position that eventually became unsustainable. Mellon overcame Taylor's reluctance to accept direct payment for his work finding, authenticating, purchasing, and shipping artworks by creating the Paul Mellon Foundation for British Art in 1963. Taylor served as the Foundation's first director. In addition to facilitating Taylor's research, the Foundation published books on British art and artists. This initial effort to create a research program that would not only complement his own collection but also further the understanding of British art foundered in 1969, leaving unrealized its most ambitious project: the fifteen-volume Paul Mellon Biographical Dictionary of British Painters in Great Britain and Ireland, 1530-1950. In its stead, a more modest endeavor has thus far yielded the following two volumes under the Paul Mellon Centre for Studies in British Art impress: Howard Colvin's A Biographical Dictionary of British Architects, 1600-1840 (1995) and the Biographical Dictionary of Sculptors in Britain, 1660-1851 by Ingrid Roscoe, Emma Hardy, and M.G. Sullivan (2009).

Paul Mellon retained his commitment to facilitating a vigorous research program in association with the care and display of his collection when he endowed the Yale Center for British Art in 1966. That the Center was affiliated with Yale University was, in fact, a consequence of Mellon's wish that it become a locus for the study of British art, not simply a museum in the conventional sense (MELLON, BASKETT, 1992, p. 322). 
Mellon had seriously considered giving his British artworks to the Virginia Museum of Fine Arts; it was Yale's prominence in the fields of English history and literature that led him finally to choose New Haven over Richmond. This setting would, Mellon believed, nourish more ambitious scholarship on British art. Not that he was interested in the Center serving as an "interdisciplinary study center": Yale's initial plan to treat the Center as a place devoted to British culture in all its forms was rejected by Mellon, who insisted that it privilege the study of art. This mandate is carried on today by the Center, which sponsors advanced art-historical research through its exhibition, postdoctoral, and residential fellowships programs. Further scholarship on British art is promoted at the Yale Center for British Art's London affiliate, the Paul Mellon Centre for Studies in British Art, which replaced the Paul Mellon Foundation for British Art in 1970. The London Centre maintains its own program of predoctoral and postdoctoral research fellowships, sponsors lectures and seminars, and oversees an active scholarly press that produces several monographs on British visual culture annually. The additional \$5 million that Mellon gave to endow the London Centre brought the total of his gift in support of the Yale Center for British Art to \$164 million, including artworks, the design and construction of the Louis I. Kahn building on the Yale campus, and funds for ongoing support. A list of Paul Mellon's charitable gifts is included as Appendix E of Reflections in a Silver Spoon (MELLON, BASKETT, 1992, p. 422-431).

No other American institution in support of advanced research in the visual arts preserves as clearly the personal vision and intention of its founder as the Yale Center for British Art. This is due not only to the specificity of his gift - a Center devoted exclusively to British art - but also to his abiding sympathy for art history as an essential branch of humanist study. The Yale Center for British Art's research programs remain inextricably entwined with Paul Mellon's collecting practices and his conception of British art and culture. His appreciation for British art was grounded in his attraction to English history and country life. Eighteenth- and nineteenth-century paintings and works on paper dominated his collection, especially landscapes, scenes of sporting life, and portraits. In this way, as unusual as his enthusiasm for British art may have been in the mid-twentieth century, Mellon's taste tended toward conventional, old-master aesthetic standards. British modernism was mostly absent from Mellon's personal collection, and contemporary art was wholly ignored. That the Yale Center for British Art would develop a research program that tends toward eighteenth- and nineteenth-century topics - with increasing forays into the early twentieth century - is no surprise, and this tendency comports entirely with the stated intentions of the institution's founder.

\section{The Clark Art Institute's Research and Academic Programs}

The research institution that provides perhaps the strongest contrast to the Yale Center's ongoing responsiveness to the intentions of its founder is the Research and Academic Programs (RAP) division of the Sterling and Francine Clark Art Institute. Robert Sterling Clark (1877-1956) inherited part of the vast fortune generated by the Singer Sewing Machine Company, which had been co-founded by his grandfather. Sterling Clark followed the example of his father, an avid art collector, and began aggressively acquiring works in 1913. That year, he embarked on a Grand Tour of sorts 
in the company of his brother Stephen and the sculptor George Grey Barnard. Barnard played the role of guide and advisor, leading the brothers through France and Italy in search of antiquities, tapestries, paintings, sculptures, and drawings. It was Barnard who facilitated Sterling Clark's first major acquisition: a portrait by Domenico Ghirlandaio. ${ }^{9}$

Sterling Clark's reliance on the eye of his mentor did not last long: by 1914, Clark felt sufficiently confident in his own judgment that he commenced his lifelong custom of keeping notes on what he believed to be the faulty attributions and poor condition of the majority of artworks he saw in galleries and in the homes of rival collectors. He occasionally expressed scorn even at much-admired examples held by the Metropolitan Museum of Art (WEBER, 2007, p. 163). Contempt might be too strong a word to describe his feeling toward art historians and other experts, but he had no interest in artworks as vehicles for intellectual inquiry. For him, art was purely a source of aesthetic pleasure and, once in his collection, of pride. His sensibilities tended toward European old masters, French Impressionism, and American naturalism. Clark's faith in his own judgment led him to acquire in 1914, for example, a rare extant painting by Piero della Francesca and, in 1916, the first of what would become a trove of thirty-nine works by Pierre-Auguste Renoir. Clark's collection, like those assembled by J. Paul Getty, Andrew W. Mellon, Samuel Kress, and Paul Mellon, emphasized European art before 1900.

Already by 1913, Clark was imagining the museum he would one day found to house the collection he intended to amass. Thirty years later, planning began in earnest. In 1945 he purchased a prominent site on Manhattan's Upper East Side where he intended to build his museum. This property was sold by Clark in 1950, however, out of fear that a nuclear attack on New York City - which he believed likely - would level the museum and obliterate his collection. A site in bucolic western Massachusetts, adjacent to Williams College, was acquired instead. Clark required that the structure be designed with durability as well as classicizing aesthetics in mind, and the building's white marble sheathing disguises a steel-reinforced concrete substructure intended to withstand a nuclear detonation as close as a mile away (WEBER, 2007, p. 241). The Sterling and Francine Clark Art Institute opened in 1955 with a charter that called for "facilities for study and research in the fine arts." ${ }^{10}$

Given Clark's disdain for art experts, it is perhaps not surprising that this provision was not immediately acted upon. Unlike his contemporary, Paul Mellon, Clark did not treat art-historical research as a natural extension of his legacy. Scholarship remained a modest part of the museum's programming for the next decade, with the addition of a research library only in 1962. This signaled a reorientation of the Clark's relationship to scholarship. A few years later, a master's program in art history was introduced to the Williams College curriculum with an explicit affiliation with the Clark Art Institute. In 1972, Michael Rinehart, the Clark's chief librarian, became the founding editor of the Répertoire de la littérature de l'art (RILA), a nearly exhaustive index of periodical scholarship in art history. RILA remained headquartered at the Clark until 1981, when the Getty Trust assumed financial responsibility (Rinehart maintained at least partial editorial responsibility until his retirement from the Clark in 2000).

Ironically, Sterling Clark's lack of interest in art-historical scholarship allowed the Clark's Research and Academic Programs to pursue its distinctive course. Having neither articulated a vision of a research program nor designated funds specifically for use in research, Sterling Clark left his museum relatively unfettered by intellectual 
prejudices and financial inflexibility. Funding for the Clark's Research and Academic Programs comes in part from the institution's endowment and also from term grants solicited to support specific initiatives. Sterling Clark's original bequest has been strengthened by endowment gifts from the Manton Foundation and the Samuel H. Kress Foundation to provide long-term support for scholarly programs. The Andrew W. Mellon Foundation has provided several term grants for the division. This combination of permanent and term funding provides stability while preventing programmatic stasis. Research programs that have been fully endowed can find it difficult to change course when scholars' needs or intellectual preoccupations shift.

When the division of Research and Academic Programs was established in 1997, the practice of art history in America was undergoing a phase of disciplinary soulsearching. This was the decade when a number of university departments of art history changed their names to signal an expansion of the field to include works of visual and material culture not conventionally classified as "art". Of course, the transformation of departments of Fine Arts or Art History into departments of Visual Culture or Visual Studies also registered a widening skepticism of the utility of "art" as a category for cultural analysis. That the Clark's leadership, then headed by Michael Conforti, was intent on positioning its Research and Academic Programs at the center of these debates was confirmed when Michael Ann Holly was chosen to head RAP in 1999. ${ }^{11}$ Holly had helped to found the first doctoral program in visual and cultural studies in the United States at the University of Rochester, and her own research addresses the history of the discipline of art history.

30 The Clark's Research and Academic Programs gave American art history an institutional framework for an overdue engagement with scholars of contemporary art and visual culture. The need for this sort of intervention was clearly evident by the mid-1990s. By this point, a full generation of American academics whose formations had taken place between the late 1970s and early 1990s, when the major independent research centers for art history were still neglecting these burgeoning areas, had established themselves professionally. Young scholars who hoped to specialize in contemporary art found themselves negotiating an institutional culture apart from that of their peers working in "historical" fields: they applied to different $\mathrm{PhD}$ programs, sought funding from different sources, wrote for different journals, attended different conferences, and faced a different employment market. Whether by necessity or inclination, scholars of contemporary art found themselves in an institutional and disciplinary culture apart. From the outset, the Clark's Research and Academic Programs division has convened conferences and produced publications devoted to art history's various - and sometimes competing - disciplinary cultures. And the Clark's program of residential fellowships has always maintained a mix of scholars of contemporary and historical art.

31 All of the major institutes for advanced research in art history now facilitate programs in support of scholarship on contemporary art. Whether this belated engagement can help to mend the disciplinary schism between practitioners of historical and contemporary studies remains to be seen. That such a division exists can no longer be doubted. Conference papers and journal articles devoted to art history's "two cultures" have provided public forums for conversations that had, for the past decade or so, been taking place privately, in department meetings or among like-minded colleagues (MAINARDI, 2011; SMITH, 2009, 2010; FOSTER, 2009). The academic study of contemporary 
art is enjoying unprecedented institutional support in the United States. Not only are independent research centers now energetically promoting scholarship in this area, but universities and colleges are hiring specialists in contemporary art at rates that outpace many historical fields. Academic publishers, too, are showing greater interest in contemporary studies. The art market, of course, leads the way in shifting institutional weight toward the global contemporary, but students, general readers, and museum-goers, too, are expressing their preference for art of the present day.

With this shift in resources, tension within the discipline of art history has naturally increased in the United States. A sort of mutual sense of alienation threatens to harden into antagonism. By bringing historical and contemporary scholars together for residencies, symposia, and other programs, America's institutes for advanced research in the visual arts can once again function as a kind of academic Switzerland. Only this time, instead of affording relief from the culture wars, America's major institutes for art-historical research might help prevent a fatal disciplinary secession.

\section{BIBLIOGRAPHY}

- BELL, 1992: Daniel Bell, “The Culture Wars: American Intellectual Life, 1965-1992," in Wilson Quarterly, Summer 1992, p. 74-107.

- BENNETT, 1992: William J. Bennett, The De-valuing of America: The Fight for Our Culture and Our Children, New York, 1992.

- BENNETT, 1988: William J. Bennett, Our Children and Our Country: Improving America's Schools and Affirming the Common Culture, New York/Toronto, 1988.

- BISHIRJIAN, 1978: Richard J. Bishirjian ed., A Public Philosophy Reader, New Rochelle, 1978.

- Colvin, 1995: Howard Colvin, A Biographical Dictionary of British Architects, 1600-1840, London, 1995.

- DAVIS, 2007: Margaret Davis, The Culture Broker: Franklin D. Murphy and the Transformation of Los Angeles, Berkeley, 2007.

- FOSTER, 2009: Hal Foster et al., “Questionnaire on 'The Contemporary'," in October, 130, Fall 2009, p. 3-124.

- HARTMAN, 2015 : Andrew Hartman, A War for the Soul of America: A History of the Culture Wars, Chicago, 2015.

- KRAMER, 1980: Hilton Kramer, "Reagan Aides Discuss U.S. Role in Helping Arts and Humanities," in New York Times, November 26, 1980, p. 1.

- MAINARDI, 2011: Patricia Mainardi, “Art History: 'Research that Matters'," ", (conference, New York, 2011), in Visual Resources, 27/4, 2011, p. 305-307 (published version of Patricia Mainardi's paper delivered in the panel "The Crisis in Art History," which she chaired at the 2011 conference in New York City).

- MELLON, BASKETT, 1992: Paul Mellon, John Baskett, Reflections in a Silver Spoon: A Memoir, New York, 1992. 
- ROSCOE, HARDY, SULLIVAN, 2009: Ingrid Roscoe, Emma Hardy, M.G. Sullivan, Biographical Dictionary of Sculptors in Britain, 1660-1851, London/New Haven, 2009.

- SMITH, 2010: Terry Smith, “The State of Art History: Contemporary Art," in The Art Bulletin, 92/4, December 2010, p. 366-383.

- SMITH, 2009: Terry Smith, What Is Contemporary Art?, Chicago, 2009.

- THOMSON, 2010: Irene Taviss Thomson, Culture Wars and Enduring American Dilemmas, Ann Arbor, 2010.

- WEBER, 2007: Nicholas Fox Weber, The Clarks of Cooperstown, New York, 2007.

\section{NOTES}

1. The Servicemen's Readjustment Act of 1944, Pub. L. No. 78-346 (1944) provided new benefits for retired military personnel who had served in the Second World War. Among the benefits available were payment of college or university tuition along with living expenses while enrolled. This law is known as the "GI Bill."

2. National Foundation on the Arts and Humanities Act of 1965, Pub. L. No. 89-209, § 2, 1965. The language of the Act was revised in 1984 and 1985.

3. On the intellectual, political, and ideological history of the culture wars, see BELL, 1992, p. 74-107. Wider-ranging accounts can be found in Irene Taviss Thomson, Culture Wars and Enduring American Dilemmas (THOMson, 2010), and Andrew Hartman, A War for the Soul of America: A History of the Culture Wars (Chicago, 2015.

4. A complete list of Getty Scholars and program themes can be found at http://getty.edu/ research/scholars/years/index.html (viewed April 28, 2015).

5. Pacific Standard Time: Los Angeles Art, 1945-1980, Rebecca Peabody et al. ed., (exh. cat., Los Angeles, The J. Paul Getty Museum, 2011), Los Angeles, 2011.

6. The financial reports of the National Gallery can be found at http://www.nga.gov/content/ ngaweb/about/financial-reports.html (viewed August 20, 2015).

7. Complete rosters of CASVA Senior Fellows, Visiting Senior Fellows, Guest Scholars, Postdoctoral and Predoctoral Fellows can be found via http://www.nga.gov/content/ngaweb/ research/casva/members.html (viewed August 20, 2015).

8. http://www.nga.gov/content/ngaweb/research/casva/fellowships.html (viewed August 20, 2015).

9. Domenico Ghirlandaio, Portrait of a Lady, ca. 1490, Williamstown, Clark Art Institute (acc. no. 1955.938).

10. http://www.clarkart.edu/rap/about (viewed August 20, 2015).

11. Michael Ann Holly succeeded RAP's first director, John Onians, who led the division for its first year. 
INDEX

Geographical index: États-Unis

Mots-clés: institut de recherche, financement, fondation

Keywords: institute for advanced study, research funding, foundation

Chronological index: 1900

\section{AUTHORS}

\section{ELIZABETH MANSFIELD}

Elizabeth Mansfield is the Vice President for Scholarly Programs at the National Humanities Center. She is the author of The Perfect Foil: François-André Vincent and the Revolution in French Painting (2011) and Too Beautiful to Picture: Zeuxis, Myth, and Mimesis (2007) and editor of the anthologies Art History and Its Institutions (2002), Making Art History (2007), and Seeing Satire (2013). 